\title{
Apoptosis and Apoptosis-Related Molecules in the Submandibular Gland of the Nonobese Diabetic Mouse Model for Sjögren's Syndrome: Limited Role for Apoptosis in the Development of Sialoadenitis
}

\author{
Saskia C. A. van Blokland, Cornelia G. van Helden-Meeuwsen, \\ Annet F. Wierenga-Wolf, Dennis Tielemans, Hemmo A. Drexhage, \\ Joop P. van de Merwe, Françoise Homo-Delarche, and Marjan A. Versnel
}

Department of Immunology (SCAVB, CGVH-M, AFW-W, DT, HAD, JPVDM, MAV), Erasmus MC - University Medical Center Rotterdam, Rotterdam, The Netherlands; and CNRS UMR 8603 (FH-D), Université Paris V, Hôpital Necker, Paris, France

\begin{abstract}
SUMMARY: Sjögren's syndrome is an autoimmune disease in which lymphocytic infiltrates develop in the exocrine glands. Pathogenetic aspects of the disease can be studied in the nonobese diabetic (NOD) mouse strain, a spontaneous model for Sjögren's syndrome. Apoptosis may play a role in the initation phase and in the effector phase of autoimmune diseases. Here, we have examined the role of apoptosis in the development of sialoadenitis in the NOD mouse. Apoptotic cells and the expression of apoptosis-related molecules were studied in submandibular glands (SMG) of NOD and NOD-scid mice before and after the onset of sialoadenitis. Numbers of apoptotic cells were not increased as compared with control mice, at any age. By immunohistochemistry, we demonstrated increased expression of Fas, Fas ligand (FasL), and bcl-2 on SMG epithelial cells of NOD and NOD-scid mice, as early as 3 days of age. mRNA expression of Fas and FasL was also examined in SMG by RQ-PCR. Low-level expression of Fas and FasL mRNA was observed in all mouse strains, from 1 day of age onward. We conclude that increased protein expression of Fas and FasL on SMG epithelial cells of NOD and NOD-scid mice probably indicates a genetically programmed abnormality in these cells that may form a trigger for the development of sialoadenitis in NOD mice. Because increased numbers of apoptotic cells were not observed, a role for actual apoptosis in the initiation or effector phase of sialoadenitis in the NOD mouse is unlikely. (Lab Invest 2003, 83:3-11).
\end{abstract}

\begin{abstract}
Sögren's syndrome is an autoimmune disease $\int$ with unknown etiology, affecting primarily the salivary and lacrimal glands. In these glands, focal lymphocytic infiltrates develop, which in some patients are accompanied by a decreased secretory response (Aziz et al, 1992; Fox, 1995, 1996). Spontaneous mouse models for Sjögren's syndrome exist in which different pathogenetic aspects of the disease can be studied. A widely used mouse model for Sjögren's syndrome is the nonobese diabetic (NOD) mouse. In this mouse strain, lymphocytic infiltrates can be detected in the salivary (sialoadenitis) and lacrimal glands (dacryoadenitis) from the age of 10 weeks onward (Humphreys-Beher et al, 1994, 1996).

The development of sialoadenitis can principally be divided in two phases. An asymptomatic phase in which unknown events lead to the activation of auto-
\end{abstract}

DOI: 10.1097/01.LAB.0000048721.21475.D1

Received June 19, 2002

Address reprint requests to: $D r$. S. C. A. van Blokland, Department of Immunology, Erasmus MC - University Medical Center Rotterdam, P.O. Box 1738, 3000 DR Rotterdam, The Netherlands. E-mail: vanblokland@immu.fgg.eur.nl reactive lymphocytes, followed by a second phase in which lymphocytic infiltrates develop and loss of secretory function can be observed. The cause of the autoimmune reaction may reside in the target organ of the autoimmune response, in the immune system, or in both. Studies in the NOD mouse indicate an important role of the target organ in the initiation of sialoadenitis. First, it has been demonstrated that 18-weekold NOD-scid mice exhibit an altered salivary protein composition as compared with control strains (Robinson et al, 1996). Because NOD-scid mice lack functional B and T lymphocytes (Shultz et al, 1995), the origin of this abnormality most likely resides in the salivary glands. Second, we have shown that the development of sialoadenitis in the NOD mouse is preceded by the accumulation of dendritic cells in the submandibular glands (SMG) (van Blokland et al, 2000). Because dendritic cells are potent antigen-presenting cells, involved in the activation of immune responses, their early accumulation in the SMG also points to a local trigger for initiation of sialoadenitis (Banchereau and Steinman, 1998; Cella et al, 1997; Stingl and Bergstresser, 1995).

Apoptosis is an important process, involved in maintenance of homeostasis of multicellular organisms (Rudin and Thompson, 1997; Thompson, 1995). 
It plays a crucial role in morphogenesis and remodeling of tissues during fetal life, in normal tissue turnover, and in maintenance of immunologic tolerance (Green and Scott, 1994; Thompson, 1995). Although apoptosis has always been considered a type of cell death that does not induce an inflammatory response, it has recently been shown that under certain circumstances apoptotic cells may induce an immune reaction. This may increase susceptibility to, or even result in the development of, an autoimmune disease (Mevorach et al, 1998; Rosen and Casciola-Rosen, 1999; Rovere et al, 1998). For example, accumulation of high numbers of apoptotic cells, because of inefficient clearing or when apoptosis occurs at a high level, may result in the production of autoantibodies to remnants of apoptotic cells. Evidence for this has been obtained in mice that are defective in the phagocytosis of apoptotic cells (Rosen and Casciola-Rosen, 2001; Scott et al, 2001). It can also be hypothesized that apoptosis results in the formation of cryptic epitopes of antigens, via cleavage of cellular substrates by enzymes that are activated after induction of apoptosis. These cryptic epitopes may subsequently induce an autoimmune response. Interestingly, induction of apoptosis in a T-cell hybridoma results in the formation of $120-\mathrm{kDa} \alpha$-fodrin (Martin et al, 1995; Vanags et al, 1996), to which autoantibodies have been detected in serum of patients with Sjögren's syndrome (Haneji et al, 1997; Watanabe et al, 1999). This illustrates that apoptosis may indeed play a role in the pathogenesis of Sjögren's syndrome. Moreover, high numbers of apoptotic cells have been shown to trigger the maturation of dendritic cells in vitro (Rovere et al, 1998). This may be mediated by the release of doublestranded DNA from dying cells, because this has been shown to induce the maturation of antigen-presenting cells (Ishii et al, 2001). So, apoptosis could contribute to the initiation of an (auto)immune reaction via the release of antigens that are normally present in the cell, via the generation of neoantigens, or via the maturation of antigen-presenting cells that may subsequently activate autoreactive lymphocytes.

Also in the effector phase of sialoadenitis, apoptosis may contribute to the destruction of glandular epithelial cells. In minor salivary glands of patients with Sjögren's syndrome, increased numbers of apoptotic epithelial cells have been detected as compared with controls. In addition, epithelial cells expressed high levels of the apoptosis receptor Fas and the deathinducing molecule Fas ligand (FasL). Infiltrating lymphocytes were shown to express FasL and bcl-2, enabling these cells to induce apoptosis, while themselves being protected from the induction of apoptotic cell death (Kong et al, 1997, 1998a; Manganelli et al, 1997; Matsumura et al, 1998).

The aim of this study was to examine the role of apoptosis in the pathogenesis of sialoadenitis in the NOD mouse. Therefore we studied the presence of apoptotic cells and the expression of apoptosisrelated molecules (Fas, FasL, and bcl-2) in SMG by immunohistochemistry. In addition, expression of Fas and FasL was studied by Western blot and by RQ-
PCR. To investigate whether disturbed apoptosis might contribute to the initiation or to the effector phase of sialoadenitis in the NOD mouse, we studied SMG of preautoimmune mice (1 day to 7 weeks) and of mice aged 12 to 20 weeks, respectively. We studied NOD-scid mice in comparison with NOD mice to delineate the role of lymphocytic infiltrates.

\section{Results \\ Presence of Apoptotic Cells in SMG of Different Mouse Strains}

Apoptotic cells, detected by terminal deoxynucleotidyl transferase-mediated dUTP nick end labeling (TUNEL) assay, were counted per $7.5 \mathrm{~mm}^{2}$ of glandular tissue. In all mouse strains, at all ages, apoptosis was mainly confined to acinar epithelial cells; hardly any apoptotic cells were present in ductuli (Fig. 1A). At the age of 3 days, increased numbers of apoptotic cells were detected in SMG of NOD, NOD-scid, and C57BL/10 mice, as compared with 5 and 20 weeks of age (Fig. 2). In NOD-scid mice, this difference was less pronounced as compared with NOD and C57BL/10 mice. At 3 days of age, no significant difference was observed between numbers of apoptotic acinar epithelial cells in the SMG of NOD and control mice. Also in glands of 5- and 20-week-old mice, numbers of apoptotic acinar epithelial cells were comparable among the different mouse strains. Within the lymphocytic infiltrates in SMG of 20-week-old NOD mice, apoptotic cells could also be observed (on average five apoptotic cells per infiltrate) (Fig. 1B).

\section{Immunohistochemical Detection of Fas, FasL, and bcl-2}

SMG of mice aged 3 days, 5 weeks, and 20 weeks were studied for the expression of Fas, FasL, and bcl-2 by immunohistochemistry. No positive staining was observed when a primary antibody was omitted or when an IgG isotype control was performed on SMG sections of NOD or C57BL/10 mice (data not shown). In glands of 3-day-old mice, it was difficult to discriminate between positive staining localized on acinar or ductal epithelial cells. For this reason, the results are described as positive staining in the parenchyma of the gland. At 5 and 20 weeks, a distinction between staining on acinar and ductal epithelial cells was made.

At 3 days of age, increased expression of Fas was observed in SMG of NOD and NOD-scid mice as compared with control mice (C57BL/10) (Table 2). This difference was more pronounced at 5 and 20 weeks, when Fas expression was not detected in the SMG of the C57BL/10 mouse, although in the NOD mouse, clear positive staining was observed on acinar and ductal epithelial cells (Table 2, Fig. 3, A and B). On acinar cells of NOD-scid mice, an intermediate level of Fas expression was detected at 5 and 20 weeks, whereas on ductal cells, Fas expression was only observed at 20 weeks.

Expression of FasL was not detected in the SMG of the C57BL/10 mouse, at any age. In the SMG of 


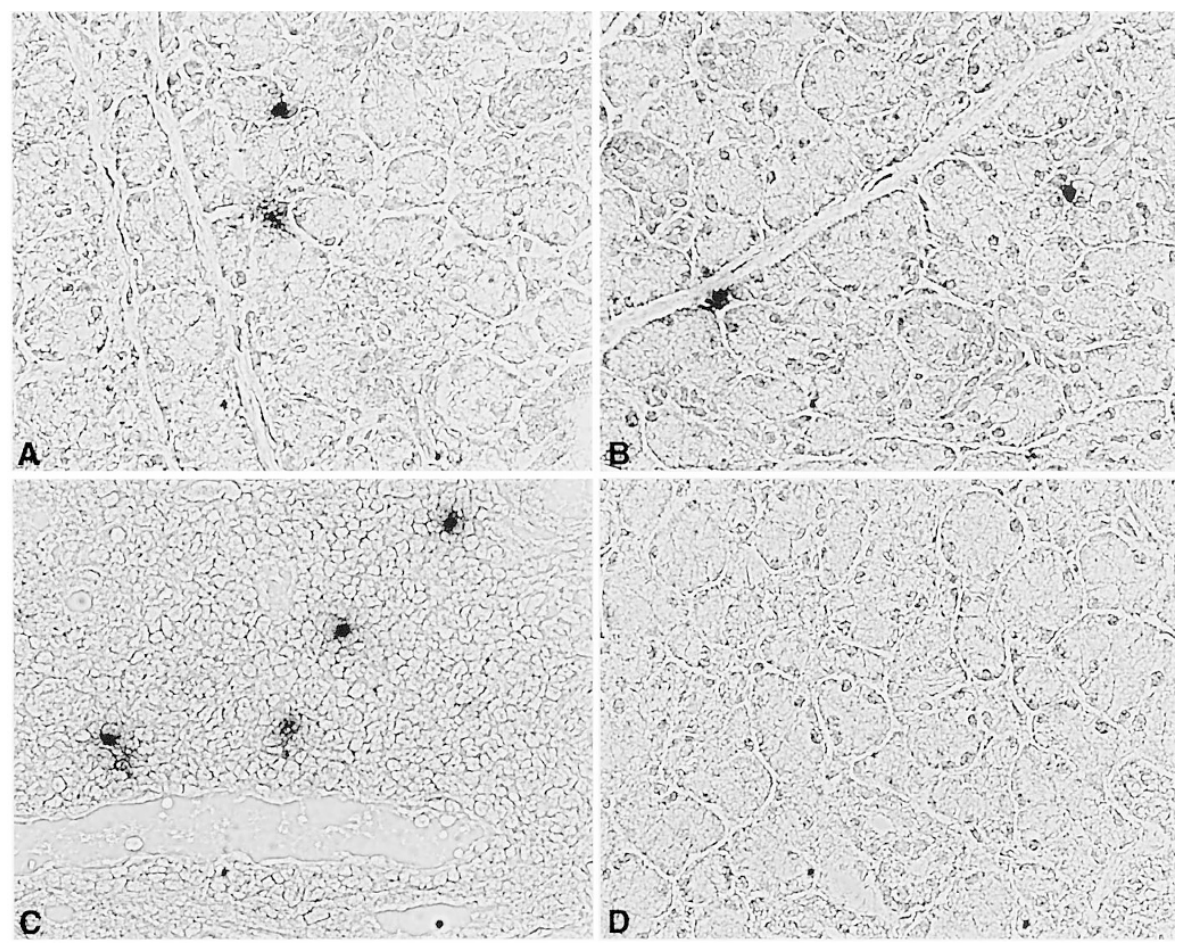

Figure 1.

Apoptotic cells, present in the submandibular gland (SMG) of nonobese diabetic (NOD) and C57BL/10 mice, as detected by terminal deoxynucleotidyl transferase-mediated dUTP nick end labeling (TUNEL) assay. A, 5-week-old NOD mouse; B, 5-week-old C57BL/10 mouse; C, lymphocytic infiltrate, in SMG of 20-week-old NOD mouse; D, negative TUNEL control in which the TdT enzyme was omitted from the reaction mixture on SMG section of a 5-week-old NOD mouse $(\times 400)$.

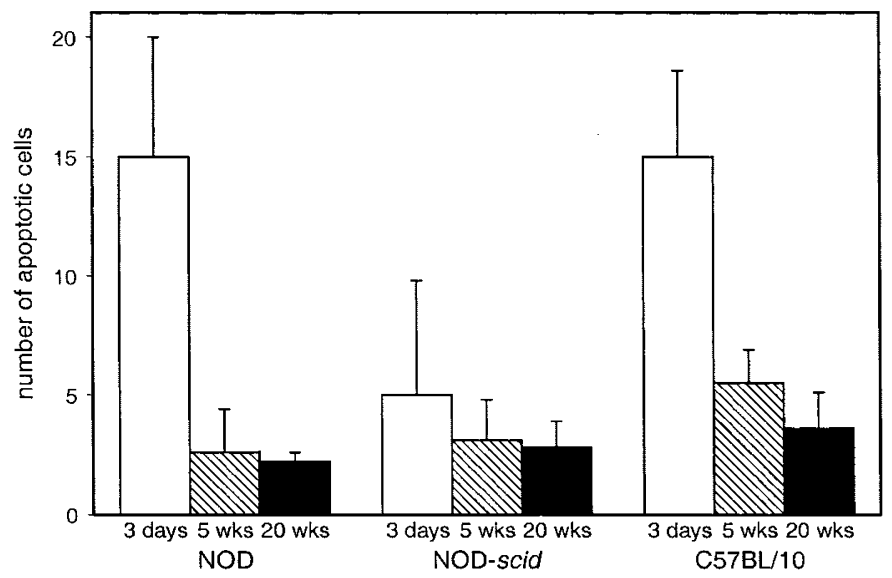

Figure 2.

Numbers of apoptotic cells, present in SMG of different mouse strains ( 3 days until 20 weeks of age), as determined by the TUNEL assay. Numbers were counted per $7.5 \mathrm{~mm}^{2}$ glandular tissue and are expressed as \pm standard deviation. Statistical analysis was performed as described in "Materials and Methods."

NOD and NOD-scid mice, on the other hand, FasL expression was observed at all ages (Table 3, Fig. 3, $C$ and D). At 5 and 20 weeks of age, FasL was observed on acinar and ductal epithelial cells; this expression was higher in NOD as compared with NOD-scid mice. Bcl-2 expression was detected in SMG of all mouse strains, from the age of 3 days until 20 weeks, but the expression level varied among the different mouse strains (Table 4). The highest expression was found in the SMG of the NOD mouse, at all ages. Expression of Fas, FasL, and bcl-2 was also examined in the SMG of the $\mathrm{BALB} / \mathrm{c}$ mouse. Results obtained in this mouse strain were similar to results we found in C57BL/10 mice (not shown). In SMG of NOD mice, lymphocytic infiltrates were detected at the age of 20 weeks. Infiltrating cells present within these infiltrates expressed high levels of Fas, FasL, and bcl-2 (not shown). So, increased expression of Fas, FasL, and bcl-2 was observed on SMG epithelial cells of 3-day-old through 20-week-old NOD and NOD-scid mice as compared with age-matched control mice. 
Table 1. Semiquantitative analysis of sections stained for the presence of Fas, FasL, and bcl-2

\begin{tabular}{ll}
\hline No positive staining cells & - \\
Few positive staining cells & $-/+$ \\
Significant number of positive staining cells & + \\
High number of positive staining cells & ++ \\
Very high number of positive staining cells & +++ \\
\hline
\end{tabular}

\section{Fas and FasL Protein Expression in SMG Lysates}

Lysates from SMG of 3- and 18-week-old NOD, NODscid, and C57BL/10 mice were subjected to Western blot analysis to study expression of Fas and FasL. At 3 weeks of age, Fas expression was observed in SMG of all mouse strains (Fig. 4A). Although the intensity of the bands was not quantified, slight variations in the intensity were observed among the different mouse strains, which are probably a result of variation in the amount of protein loaded on the gel. A similar picture was observed at 7 weeks (not shown) and 18 weeks of age, at which times Fas expression was observed in SMG of all mouse strains (Fig. 4B). No signal was observed when the anti-Fas antibody was substituted by an isotype control antibody. In addition, preincubation of the primary antibody with a Fas blocking peptide inhibited the positive signal observed in the samples (Fig. 4A). Expression of FasL was found in SMG lysates of 3- and 18-week-old NOD, NOD-scid, and C57BL/10 mice (Fig. 4, C and D). Substitution of the primary antibody with an isotype control resulted in absence of a positive signal.

\section{Quantification of Fas and FasL mRNA by RQ-PCR}

$\mathrm{RQ}-\mathrm{PCR}$ was performed to examine and quantitate Fas and FasL mRNA expression in SMG of the different mouse strains. A standard curve was generated in each experiment in which the threshold cycle was plotted against the starting quantity of input cDNA. This curve was used to deduce the starting quantity of the individual samples, in arbitrary units. To standardize for the amount of RNA that was used in the reverse transcriptase reaction, values obtained in experiments in which Fas or FasL expression was examined were divided by the corresponding values for glyceraldehyde-3-phosphate dehydrogenase (GAPDH) expression. In Tables 5 and 6, the expression levels of Fas and FasL (average of the two pools) in the different mouse strains at different ages are mentioned. These levels are corrected for the amount of input RNA used to generate cDNA. The $C_{t}$ value (threshold cycle) is a measure of the amount of template in the sample. $\mathrm{C}_{t}$ values for Fas and FasL were high as compared with $\mathrm{C}_{t}$ values for GAPDH (5-7 $\mathrm{C}_{t}$ higher for Fas, 7-10 $\mathrm{C}_{t}$ higher for FasL, with similar amounts of input CDNA in the RQ-PCR reaction), which means that 5 to 10 extra amplification cycli are needed to detect a signal for Fas or FasL than the number of cycli needed to detect GAPDH.
Table 2. Fas protein expression in SMG of different mouse strains

\begin{tabular}{|c|c|c|c|c|c|}
\hline & \multirow{2}{*}{$\frac{\text { Parenchyma }}{3 \text { days }}$} & \multicolumn{2}{|c|}{$\begin{array}{l}\text { Acinar } \\
\text { epithelial } \\
\text { cells }\end{array}$} & \multicolumn{2}{|c|}{$\begin{array}{l}\text { Ductal } \\
\text { epithelial } \\
\text { cells }\end{array}$} \\
\hline & & 5 wk & 20 wk & 5 wk & 20 wk \\
\hline NOD & $+/++$ & ++ & +++ & + & ++ \\
\hline NOD-scid & $+1++$ & $-1+$ & + & - & + \\
\hline C57BL/10 & + & - & - & - & - \\
\hline
\end{tabular}

We conclude that Fas mRNA expression occurs in all mouse strains, from 1 day through 18 weeks of age, albeit at low levels. Taking into consideration the variation among the different age groups, and among the two control strains, no major differences are detected between the NOD and NOD-scid on the one hand, and the control strains on the other hand, at any age. Furthermore, between the individual mouse strains, no significant difference in Fas mRNA expression is observed in time. FasL mRNA expression is absent in all mouse strains at 1 day of age. At 3 and 7 weeks of age, expression is low in NOD, NOD-scid, and C57BL/10 mice and still absent in BALB/c mice. Although FasL mRNA expression remains low at 12 and 18 weeks of age in the NOD-scid and C57BL/10 mice, it is increased in the NOD mouse.

\section{Discussion}

In this study we used immunohistochemistry to demonstrate increased expression of the proapoptotic molecules Fas and FasL in SMG epithelial cells of mice of the NOD strain as compared with control mice. This increased expression was already observed as early as 3 days of age and was not accompanied by increased numbers of apoptotic epithelial cells. This may be because of the concurrent increased expression of the antiapoptotic bcl-2 on the salivary gland epithelial cells, which was most obvious in the NOD mouse. Furthermore, whether a cell undergoes apoptosis or not can be influenced by a list of factors that is ever increasing, of which we studied only three factors (Nagata, 1997; Wang and Lenardo, 1997).

A concern of this study is that increased expression of Fas and FasL was only identified by immunohistochemistry. Western blot analysis of SMG lysates revealed Fas and FasL expression in 3- to 18-week-old NOD and NOD-scid mice but also in C57BL/10 mice.

Kong et al (1998b) described increased numbers of apoptotic epithelial cells in SMG of 18-week-old NOD and NOD-scid mice as compared with control mice and suggested an important contribution of apoptosis to the development of sialoadenitis. In glands of 8-week-old mice, similar numbers of apoptotic cells were detected. By immunohistochemistry and on the mRNA level, constitutive expression of FasL in both NOD and NOD-scid and in BALB/c mice aged 8 and 18 weeks was described. Fas protein expression, on 


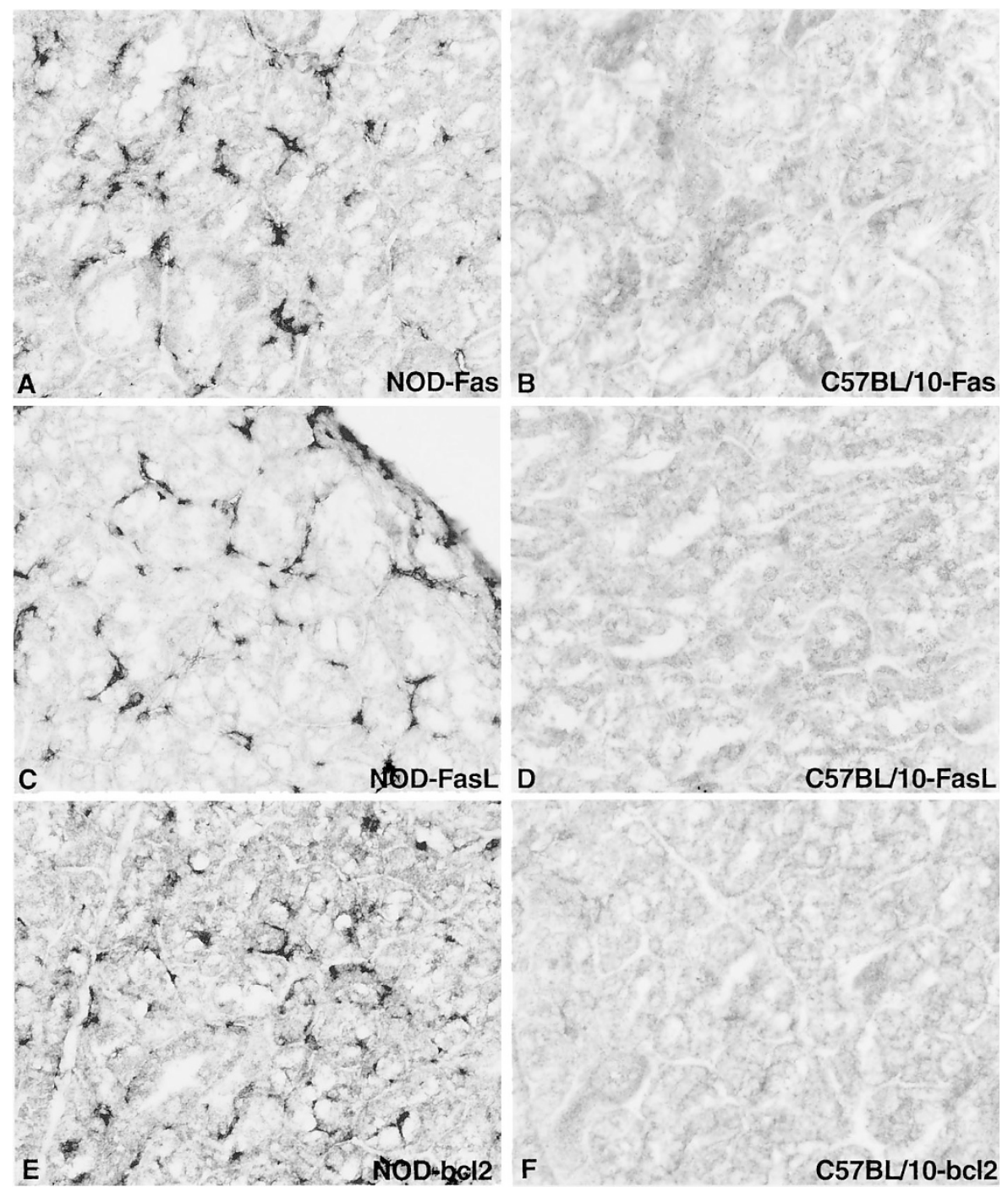

Figure 3.

Immunohistochemical detection of Fas, Fas ligand (FasL), and bcl-2 expression in SMG of NOD and C57BL/10 mice, at 5 weeks of age $(\times 400)$. No positive staining was observed when a primary antibody was omitted or when an IgG isotype control was performed.

Table 3. FasL protein expression in SMG of different mouse strains

\begin{tabular}{|c|c|c|c|c|c|}
\hline & \multirow{2}{*}{$\frac{\text { Parenchyma }}{3 \text { days }}$} & \multicolumn{2}{|c|}{$\begin{array}{l}\text { Acinar } \\
\text { epithelial } \\
\text { cells }\end{array}$} & \multicolumn{2}{|c|}{$\begin{array}{l}\text { Ductal } \\
\text { epithelial } \\
\text { cells }\end{array}$} \\
\hline & & 5 wk & 20 wk & 5 wk & $20 w k$ \\
\hline NOD & + & ++ & ++ & + & ++ \\
\hline NOD-scid & + & $+1-$ & + & $-/+$ & + \\
\hline C57BL/10 & - & - & - & - & - \\
\hline
\end{tabular}

the other hand, was restricted to SMG of 18-week-old NOD and NOD-scid mice, but Fas mRNA expression was low. Our study does not support their findings. The reason for the discrepancy between their and our results may reside in a different source of the antibodies used for immunohistochemistry. Furthermore, differences in housing conditions of NOD mice may influence the outcome of experiments in different
Table 4. Bcl-2 protein expression in SMG of different mouse strains

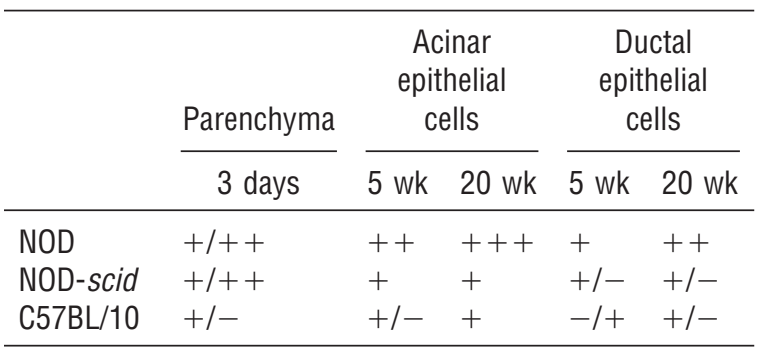

laboratories, although this is unlikely to result in major discrepancies other than kinetics of the disease.

Our results have important implications with regard to the potential role of actual apoptosis in the development of sialoadenitis. Although a role of apoptosis in the effector phase of sialoadenitis in the NOD mouse was suggested after the study of Kong et al (Elkon, 1998; Humphreys-Beher et al, 1999; Kong et 


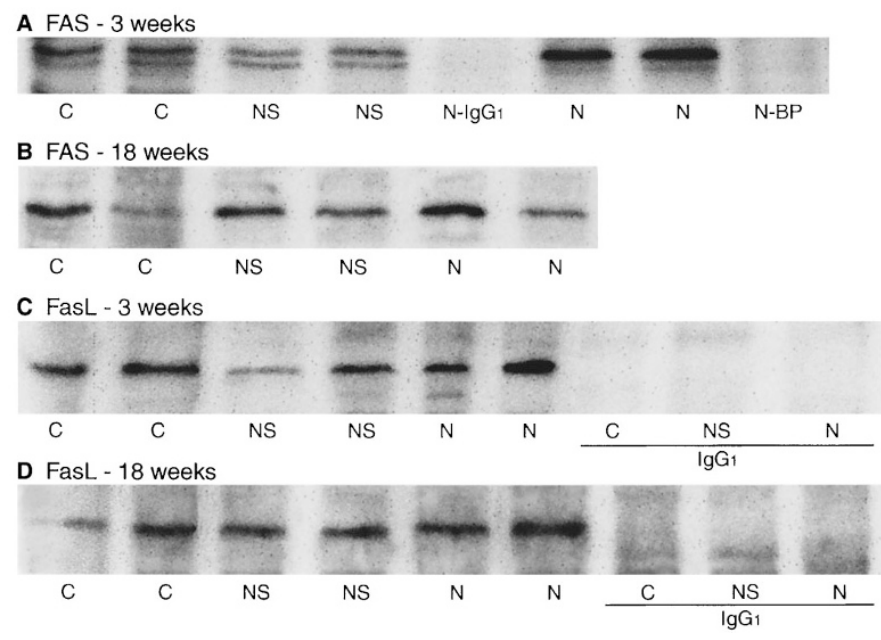

Figure 4.

Western blot analysis of Fas ( $A$ and $B$ ) and FasL ( $C$ and $D$ ) expression in SMG lysates of NOD, NOD-scid, and C57BL/10 mice aged 3 weeks $(A$ and $C)$ and 18 weeks $(\mathrm{B}$ and $\mathrm{D}) . \mathrm{C}=\mathrm{C} 57 \mathrm{BL} / 10 ; N S=\mathrm{NOD}-\mathrm{scid} ; N=\mathrm{NOD} ; \lg G 1=\lg \mathrm{G} 1$ isotype control as primary antibody; $B P=$ Preincubation of primary antibody with blocking peptide.

Table 5. Expression of Fas mRNA in SMG of different mouse strains ${ }^{a}$

\begin{tabular}{lccccc}
\hline & 1 day & 3 wk & 7 wk & 12 wk & 18 wk \\
\hline NOD & 1.5 & 1.0 & 0.5 & 1.0 & 0.8 \\
NOD-scid & 1.2 & 1.1 & 0.9 & 0.7 & 0.9 \\
C57BL/10 & 0.9 & 1.8 & 0.7 & 0.3 & 0.5 \\
BALB/c & 0.9 & 0.3 & 0.6 & 0.7 & 0.8 \\
\hline
\end{tabular}

${ }^{a}$ Expression levels are corrected for GAPDH mRNA expression.

Table 6. Expression of FasL mRNA in SMG of different mouse strains ${ }^{a}$

\begin{tabular}{lccccc}
\hline & 1 day & 3 wk & 7 wk & 12 wk & 18 wk \\
\hline NOD & 0 & 0.3 & 0.1 & 0.5 & 0.5 \\
NOD-scid & 0 & 0.3 & 0.1 & 0 & 0.2 \\
C57BL/10 & 0 & 0.4 & 0.3 & 0 & 0.1 \\
BALB/c & 0 & 0 & 0 & 0.1 & 0.5 \\
\hline
\end{tabular}

${ }^{a}$ Expression levels are corrected for GAPDH mRNA expression.

al, 1998b), our results do not support this. In addition, in our experiments we did not find evidence for a role of apoptosis in the initiation phase of sialoadenitis. Interestingly, controversy also exists on the role of apoptosis in patients with Sjögren's syndrome. Although apoptosis has been proposed as an important mechanism in the effector phase of the disease (Kong et al, 1997, 1998a; Manganelli et al, 1997; Matsumura et al, 1998), Fas-induced apoptosis was recently reported to be rare in minor salivary glands of patients with Sjögren's sydrome, despite expression of Fas and FasL (Ohlsson et al, 2001). Because fixation and pretreatment of the sections may influence the outcome of the TUNEL staining (Labat-Moleur et al, 1998; Negoescu et al, 1996), careful comparison with the control tissue is critical in the evalutation of TUNELstained sections.
Increased expression of Fas, FasL, and bcl-2 in NOD SMG, detected by immunohistochemical methods, may be the outcome of dysregulated gene expression, resulting in activation of the cells. As has been suggested for other abnormalities that have been described in NOD SMG (Cha et al, 2001; Robinson et al, 1996), it may reflect a genetically programmed abnormality, intrinsic to the SMG, leading to increased susceptibility to the development of sialoadenitis.

\section{Materials and Methods}

\section{Mice and Experimental Design}

Female NOD, NOD-scid, and C57BL/10 mice were bred in our own facilities under specific pathogen-free conditions. Specific pathogen-free BALB/c mice were purchased from Harlan (Horst, The Netherlands). Mice were fed standard pellets and water ad libitum and were maintained at $22^{\circ} \mathrm{C} \pm 1^{\circ} \mathrm{C}$ on a 12-hour light/ 12-hour dark cycle. Under these conditions, the incidence of diabetes in NOD mice at 30 weeks of age was $90 \%$ in females and $30 \%$ in males. SMG of 3-day-old mice were obtained from Hospital Necker, Paris, France, where the mice were housed under the same conditions. Ten mice of each mouse strain of this age were used, whereas 5 mice per strain of the other age groups were used.

\section{Tissue Preparation}

Mice aged 3 weeks and older were killed by asphyxiation with carbon dioxide. Mice younger than 3 weeks were killed by cervical dislocation. For immunohistochemistry, SMG were removed, embedded in Tissue-tek (Sakura Finetek, Torrance, California), and snap-frozen in liquid nitrogen. Tissues were stored at $-80^{\circ} \mathrm{C}$. For RNA analysis, SMG were removed, homogenized in RNAzol B (Campro Scientific, 
Veenendaal, The Netherlands), and stored at $-80^{\circ} \mathrm{C}$ until further processing. Salivary gland lysates were prepared by homogenization of SMG in ice-cold Hanks' buffer (Life Technologies, Paisley, United Kingdom) supplemented with Protease Inhibitor Cocktail (Boehringer Mannheim, Mannheim, Germany), 1 tablet in $10 \mathrm{ml}$ Hanks' buffer. The lysates were stored at $-80^{\circ} \mathrm{C}$.

\section{Immunohistochemistry}

Cryostat sections $(6 \mu \mathrm{m})$ were prepared and mounted on coated microscopic slides. Slides that were used for the immunohistochemical detection of Fas, FasL, and bcl-2 were fixed with methanol $\left(-20^{\circ} \mathrm{C}\right)$ and aceton (room temperature) and rinsed with PBS $(\mathrm{pH}$ 7.8) at room temperature. To block for endogenous biotin-like structures, an avidin/biotin blocking kit was used (Vector Laboratories, Burlingame, California). The slides were incubated with anti-Fas (Ab-1; Calbiochem, Darmstadt, Germany), anti-FasL (C178), or antibcl-2 antibody (N19) (both from Santa Cruz Biotechnology, Santa Cruz, California), for 1 hour at room temperature. As a negative control, the primary antibody was omitted. In addition, the specificity of the antibodies was confirmed by an isotype control (rabbit IgG; Santa Cruz Biotechnology).

Subsequently, the slides were incubated for 30 minutes (45 minutes in the case of anti-FasL and anti-bcl-2 stainings) with biotinylated goat anti-rabbit immunoglobulins (Biogenex, San Ramon, California), diluted $1: 50$ in PBS/0.1\% BSA, to which $10 \%$ normal mouse serum was added. This was followed by an incubation period of 45 minutes (30 minutes in the case of anti-Fas and anti-bcl-2 stainings) with horseradish peroxidase-conjugated avidin/biotin complex (DAKO, Glostrup, Denmark), diluted 1:100 in PBS. Then the peroxidase label was developed by exposure to $0.10 \%(\mathrm{w} / \mathrm{v})$ diaminobenzidine in acetate buffer $(\mathrm{pH}$ 6.0) containing $1 \% \quad \mathrm{NiSO}_{4}$ and $0.02 \% \quad \mathrm{H}_{2} \mathrm{O}_{2}$ for 3 minutes. The slides were counterstained with nuclear fast red $(0.1 \%[\mathrm{w} / \mathrm{v}]$ solution in water containing $5 \%$ $\left.[\mathrm{w} / \mathrm{v}] \mathrm{Al}_{2}\left(\mathrm{SO}_{4}\right)_{3}\right)$, dehydrated by an ethanol/xylene series, and embedded with Depex mounting medium (BDH, Poole, England). In between all incubations, the slides were rinsed with PBS. The slides were semiquantitatively analyzed by two independent individuals, according to Table 1. Slides that were used for the TUNEL assay were fixed for 10 minutes in a 4\% paraformaldehyde solution ( $\mathrm{pH}$ 7.4) (Merck, Darmstadt, Germany), at $4^{\circ} \mathrm{C}$, and refixated with ethanol/glacial acetic acid $(2: 1)$ at $-20^{\circ} \mathrm{C}$. Thereafter the sections were presoaked with $50 \mu \mathrm{l}$ of TdT buffer $(100 \mathrm{~mm}$ sodiumcacodylate, $1 \mathrm{~mm}$ cobalt chloride, $0.1 \mathrm{~mm}$ dithiothreitol, and $0.005 \%$ BSA) for 5 minutes at room temperature. Subsequently, $50 \mu$ l of TdT solution was added, containing $20 \mathrm{U}$ of TdT (Pharmacia Biotech, Uppsala, Sweden), $20 \mu \mathrm{M}$ dNTP (Pharmacia Biotech), and $2 \mu \mathrm{M}$ digoxygenin-labeled dUTP (Boehringer Mannheim), which was followed by an incubation period of 1 hour at $37^{\circ} \mathrm{C}$. As a negative control, TdT was omitted.
After the incubation period, the reaction was stopped by washing for 30 minutes with $2 \times$ SSC, containing $3 \mathrm{~m}$ sodium chloride and $0.3 \mathrm{M}$ trisodium citrate, at $37^{\circ} \mathrm{C}$. Thereafter the slides were rinsed with PBS, as in between all incubation steps so far, and subsequently with Tris-buffered saline (TBS) $(\mathrm{pH} 7.6)$, containing $0.1 \%(\mathrm{v} / \mathrm{v})$ Triton $\mathrm{X}-100$ and $0.1 \%$ BSA. This was followed by an incubation with alkaline phosphatase labeled anti-digoxygenin $\mathrm{F}(\mathrm{ab})_{2}$ fragments (Boehringer Mannheim), $1.5 \mathrm{U} / \mathrm{ml}$ in TBS supplemented with $2 \%$ fetal calf serum (BioWhittaker, Verviers, Belgium) for 30 minutes at room temperature. Thereafter the slides were placed in a Fast Blue substrate (Sigma, St. Louis, Missouri) solution for 30 minutes at room temperature, in a dark room. This reaction was stopped by washing for 10 minutes in PBS, after which the sections were counterstained with nuclear fast red (Fluka Chemica, Neu-Ulm, Swiss) and embedded in Kayser's glycerol gelatin (Merck).

The sections were evaluated by counting the number of positive staining cells per $7.5 \mathrm{~mm}^{2}$, by two independent individuals. The differences between the means were evaluated by the Mann-Whitney twosample two-tailed signed-rank test. A $p$ value less than 0.05 was considered statistically significant.

\section{Western Blot Analysis}

Salivary gland lysates were thawed, sonicated twice for 30 seconds, and centrifuged at $10000 \times g, 4^{\circ} \mathrm{C}$, for 10 minutes, after which the supernatant was carefully removed. Protein concentration in the supernatant was determined using the Bio-Rad protein assay (Bio-Rad Laboratories $\mathrm{GmbH}$, München, Germany). Per lane, $50 \mu \mathrm{g}$ of protein was electrophoresed in a $12.5 \%$ SDS-polyacrylamide gel. Then protein was transferred to nitrocellulose (hybond ECL nitrocellulose membrane; Amersham Pharmacia Biotech, Little Chalfont, England), blocked for 1 hour in TBS (pH 7.4) supplemented with $0.1 \%$ Tween (TBS-T) containing $5 \%$ nonfat milk and $1 \%$ bovine serum albumin. The nitrocellulose membranes were incubated overnight at $4^{\circ} \mathrm{C}$ with either anti-Fas antibody $(0.5 \mu \mathrm{g} / \mathrm{ml}, \mathrm{A} 20$; Santa Cruz Biotechnology) or anti-FasL antibody (1 $\mu \mathrm{g} / \mathrm{ml}, \mathrm{C} 178$; Santa Cruz Biotechnology).

The anti-Fas antibody used in the Western blot experiments was of a different source than the antiFas antibody used for immunohistochemistry, because the latter antibody was not suitable for Western blot analysis. As a negative control, the primary antibody was substituted by an isotype control (rabbit IgG; Santa Cruz Biotechnology). To control for the specificity of the anti-Fas antibody, the antibody (A20) was neutralized with the corresponding blocking peptide (Santa Cruz Biotechnology) by incubation with a 8-fold excess of blocking peptide for 2 hours at $4^{\circ} \mathrm{C}$, before addition to the nitrocellulose filters. The membranes were washed for 1 hour with TBS-T, after which they were incubated with horseradish peroxidase-conjugated swine anti-rabbit antibody $(2 \mu \mathrm{g} / \mathrm{ml}$; DAKO) in the presence of $2 \%$ normal mouse serum. 
Blots were developed with chemiluminescence substrate (ECL; Amersham Pharmacia Biotech).

\section{RNA Extraction and cDNA Synthesis}

Total RNA was extracted from SMG tissues that were homogenized in RNAzol B, according to the manufacturer's protocol. The OD260 and OD280 were measured to determine the yield and purity of the RNA. Target RNA $(1 \mu \mathrm{g})$ was reverse transcribed using the following (per reaction): $5 \mathrm{U}$ of AMV-RTase, $2 \mu \mathrm{l}$ of $10 \times$ AMV RT buffer, $1 \mu \mathrm{l}$ of $20 \mathrm{~mm}$ dNTP mix, $2 \mu \mathrm{l}$ of $10 \mathrm{~mm}$ spermine/ $\mathrm{HCl}, 1 \mu \mathrm{l}$ of $40 \mathrm{U} / \mu \mathrm{l}$ RNA guard, 0.5 $\mu \mathrm{l}$ of $100 \mathrm{OD} / \mathrm{ml}$ random hexamers, and $2 \mu \mathrm{l}$ of 100 $\mu \mathrm{g} / \mathrm{ml}$ oligo(dT) ${ }_{15}$. This reaction mixture was adjusted with $\mathrm{H}_{2} \mathrm{O}$ to a total volume of $20 \mu \mathrm{l}$, incubated at $41^{\circ} \mathrm{C}$ for 1 hour, and stored at $-80^{\circ} \mathrm{C}$. Of each mouse strain, two pools of RNA were used per age group, which consisted of three mice per pool.

\section{Primers and Probes}

PCR primers and fluorogenic probes for the target genes were designed using the computer program Primer Express and were purchased from PE Biosystems (Branchburg, New Jersey). The oligonucleotide sequences of the primers, used for the detection of Fas, FasL, and GAPDH, are as follows: Fas 3', ATG CAT CAC TCT TCC CAT GAG A; Fas 5', GGA GGG CAA GAT AGA TGA GAT CA; FasL 3', AAC CCA GTT TCG TTG ATC ACA A; FasL 5', CCA ACC AAA GCC TTA AAG TAT CAT C; GAPDH 3', TTC ACC ACC ATG GAG AAG GC; and GAPDH 5', GGC ATG GAC TGT GGT CAT GA. The oligonucleotide sequences of the fluorogenic probes are as follows: Fas, AGT CCA GCT GCT CCT GTG CTG GTA; FasL, CAT TTA ACA GGG AAC CCC CAC TCA AGG T; and GAPDH, TGC ATC CTG CAC CAC CAA CTG CTT AG. The fluorogenic probes contained a reporter dye (FAM) covalently attached to the $5^{\prime}$ end and a quencher dye (TAMRA) covalently attached to the $3^{\prime}$ end. Extension from the $3^{\prime}$ end was blocked by attachment of a 3 ' phosphate group.

\section{PCR Amplification}

PCR reactions were performed in the $\mathrm{ABI}$-prism 7700 sequence detector, which contains a Gene-Amp PCR System 9600 (Perkin Elmer/Applied Biosystems, Foster City, California). Reaction conditions were programmed on a Power Macintosh 7200. PCR amplifications were performed in a total volume of $50 \mu \mathrm{l}$, containing $2 \mu \mathrm{l}$ of cDNA sample, $25 \mu \mathrm{l}$ of $2 \times$ Taqman Universal PCR Master Mix (PE Biosystems), and 900 $\mathrm{nM}$ of each primer (for Fas and GAPDH detection). Each reaction also contained $200 \mathrm{~nm}$ of the corresponding detection probe (for Fas and GAPDH detection). For the detection of FasL expression, 1200 nм of each primer and $250 \mathrm{~nm}$ of the detection probe were used. PCR amplification reactions were performed in duplicate wells, using the following conditions: 2 minutes at $50^{\circ} \mathrm{C}$ and 10 minutes at $95^{\circ} \mathrm{C}$, followed by a total of 50 two-temperature cycles (15 seconds at $95^{\circ} \mathrm{C}$ and 1 minute at $60^{\circ} \mathrm{C}$ ).

\section{Acknowledgements}

We gratefully acknowledge Professor Dr. R. Benner for critical reading of the manuscript. Mr. T. M. van Os is gratefully acknowledged for excellent photographic assistance and preparation of the figures.

\section{References}

Aziz KE, Montanaro A, McCluskey PJ, and Wakefield D (1992). Sjögren's syndrome: review with recent insights into immunopathogenesis. Austr N Z J Med 22:671-678.

Banchereau J and Steinman RM (1998). Dendritic cells and the control of immunity. Nature 392:245-252.

Cella M, Sallusto F, and Lanzavecchia A (1997). Origin, maturation and antigen presenting function of dendritic cells. Curr Opin Immunol 9:10-16.

Cha S, Van Blokland SCA, Versnel MA, Homo-Delarche F, Nagashima H, Brayer J, Peck AB, and Humphreys-Beher MG (2001). Abnormal organogenesis in salivary gland development may initiate adult onset of autoimmune exocrinopathy. Exp Clin Immunogenet 18:143-160.

Elkon KB (1998). Fas (APO-1/CD95)-assisted suicide in NOD exocrine glands. Clin Exp Rheumatol 16:659-661.

Fox RI (1995). Sjögren's syndrome. Curr Opin Rheumatol 7:409-416.

Fox RI (1996). Clinical features, pathogenesis, and treatment of Sjögren's syndrome. Curr Opin Rheumatol 8:438-445.

Green DR and Scott DW (1994). Activation-induced apoptosis in lymphocytes. Curr Opin Immunol 6:476-487.

Haneji N, Nakamura T, Takio K, Yanagi K, Higashiyama H, Saito I, Noji S, Sugino H, and Hayashi Y (1997). Identification of alpha-fodrin as a candidate autoantigen in primary Sjogren's syndrome. Science 276:604-607.

Humphreys-Beher MG (1996). Animal models for autoimmune disease-associated xerostomia and xerophthalmia. Adv Dent Res 10:73-75.

Humphreys-Beher MG, Hu Y, Nakagawa Y, Wang PL, and Purushotham KR (1994). Utilization of the non-obese diabetic (NOD) mouse as an animal model for the study of secondary Sjogren's syndrome. Adv Exp Med Biol 350:631-636.

Humphreys-Beher MG, Peck AB, Dang H, and Talal N (1999). The role of apoptosis in the initiation of the autoimmune response in Sjogren's syndrome. Clin Exp Immunol 116:383387.

Ishii KJ, Suzuki K, Coban C, Takeshita F, Itoh Y, Matoba H, Kohn LD, and Klinman DM (2001). Genomic DNA released by dying cells induces the maturation of APCs. J Immunol 167:2602-2607.

Kong L, Ogawa N, McGuff HS, Nakabayashi T, Sakata KM, Masago R, Vela-Roch N, Talal N, and Dang H (1998a). Bcl-2 family expression in salivary glands from patients with primary Sjogren's syndrome: Involvement of Bax in salivary gland destruction. Clin Immunol Immunopathol 88:133-141.

Kong L, Ogawa N, Nakabayashi T, Liu GT, E DS, McGuff HS, Guerrero D, Talal N, and Dang H (1997). Fas and Fas ligand 
expression in the salivary glands of patients with primary Sjogren's syndrome. Arthritis Rheum 40:87-97.

Kong L, Robinson CP, Peck AB, Vela-Roch N, Sakata KM, Dang H, Talal N, and Humphreys-Beher MG (1998b). Inappropriate apoptosis of salivary and lacrimal gland epithelium of immunodeficient NOD-scid mice. Clin Exp Rheumatol $16: 675-681$.

Labat-Moleur F, Guillermet C, Lorimier P, Robert C, Lantuejoul S, Brambilla E, and Negoescu A (1998). TUNEL apoptotic cell detection in tissue sections: critical evaluation and improvement critical evaluation and improvement. J Histochem Cytochem 46:327-334.

Manganelli P, Quaini F, Andreoli AM, Lagrasta C, Pilato FP, Zuccarelli A, Monteverdi R, D'Aversa C, and Olivetti G (1997). Quantitative analysis of apoptosis and bcl-2 in Sjogren's syndrome. J Rheumatol 24:1552-1557.

Martin SJ, O’Brien GA, Nishioka WK, McGahon AJ, Mahboubi A, Saido TC, and Green DR (1995). Proteolysis of fodrin (non-erythroid spectrin) during apoptosis. J Biol Chem 270: 6425-6428.

Matsumura R, Umemiya K, Kagami M, Tomioka H, Tanabe E, Sugiyama T, Sueishi M, Nakajima A, Azuma M, Okumura K, and Sumida T (1998). Glandular and extraglandular expression of the Fas-Fas ligand and apoptosis in patients with Sjogren's syndrome. Clin Exp Rheumatol 16:561-568.

Mevorach D, Zhou JL, Song X, and Elkon KB (1998). Systemic exposure to irradiated apoptotic cells induces autoantibody production. J Exp Med 188:387-392.

Nagata S (1997). Apoptosis by death factor. Cell 88:355-365.

Negoescu A, Lorimier P, Labat-Moleur F, Drouet C, Robert C, Guillermet C, Brambilla C, and Brambilla E (1996). In situ apoptotic cell labeling by the TUNEL method: Improvement and evaluation on cell preparations. J Histochem Cytochem 44:959-968.

Ohlsson M, Skarstein K, Bolstad Al, Johannessen AC, and Jonsson R (2001). Fas-induced apoptosis is a rare event in Sjogren's syndrome. Lab Invest 81:95-105.

Robinson CP, Yamamoto $H$, Peck $A B$, and HumphreysBeher MG (1996). Genetically programmed development of salivary gland abnormalities in the NOD (nonobese diabetic)scid mouse in the absence of detectable lymphocytic infiltration: A potential trigger for sialoadenitis of NOD mice. Clin Immunol Immunopathol 79:50-59.

Rosen A and Casciola-Rosen L (1999). Autoantigens as substrates for apoptotic proteases: implications for the pathogenesis of systemic autoimmune disease. Cell Death Differ 6:6-12.
Rosen A and Casciola-Rosen L (2001). Clearing the way to mechanisms of autoimmunity. Nat Med 7:664-665.

Rovere $\mathrm{P}$, Vallinoto $\mathrm{C}$, Bondanza A, Crosti MC, Rescigno M, Ricciardi-Castagnoli P, Rugarli C, and Manfredi AA (1998). Bystander apoptosis triggers dendritic cell maturation and antigen-presenting function. J Immunol 161:4467-4471.

Rudin CM and Thompson CB (1997). Apoptosis and disease: Regulation and clinical relevance of programmed cell death. Annu Rev Med 48:267-281.

Scott RS, McMahon EJ, Pop SM, Reap EA, Caricchio R, Cohen PL, Earp HS, and Matsushima GK (2001). Phagocytosis and clearance of apoptotic cells is mediated by MER. Nature 411:207-211.

Shultz LD, Schweitzer PA, Christianson SW, Gott B, Schweitzer IB, Tennent B, McKenna S, Mobraaten L, Rajan TV, Greiner DL, and Leiter EH (1995). Multiple defects in innate and adaptive immunologic function in NOD/LtSz-scid mice. J Immunol 154:180-191.

Stingl G and Bergstresser PR (1995). Dendritic cells: A major story unfolds. Immunol Today 16:330-333.

Thompson CB (1995). Apoptosis in the pathogenesis and treatment of disease. Science 267:1456-1462.

Vanags DM, Porn-Ares MI, Coppola S, Burgess DH, and Orrenius S (1996). Protease involvement in fodrin cleavage and phosphatidylserine exposure in apoptosis. J Biol Chem 271:31075-31085.

van Blokland SCA, van Helden-Meeuwsen CG, WierengaWolf AF, Drexhage HA, Hooijkaas H, van de Merwe JP, and Versnel MA (2000). Two different types of sialoadenitis in the NOD- and MRL/lpr mouse models for Sjögren's syndrome: A differential role for dendritic cells in the initiation of sialoadenitis? Lab Invest 80:575-585.

Wang $\mathrm{J}$ and Lenardo MJ (1997). Molecules involved in cell death and peripheral tolerance. Curr Opin Immunol 9:818825 .

Watanabe T, Tsuchida T, Kanda N, Mori K, Hayashi Y, and Tamaki K (1999). Anti-alpha-fodrin antibodies in Sjogren syndrome and lupus erythematosus. Arch Dermatol 135 535-539. 